\title{
The Removal of Uranium onto Nanoscale Zero-Valent Iron Particles in Anoxic Batch Systems
}

\author{
Richard A. Crane and Thomas B. Scott \\ Interface Analysis Centre, University of Bristol, UK \\ Correspondence should be addressed to Richard A. Crane; richardandrewcrane@gmail.com \\ Received 14 January 2014; Revised 14 February 2014; Accepted 14 February 2014; Published 22 May 2014 \\ Academic Editor: Jie-Fang Zhu
}

Copyright ( 2014 R. A. Crane and T. B. Scott. This is an open access article distributed under the Creative Commons Attribution License, which permits unrestricted use, distribution, and reproduction in any medium, provided the original work is properly cited.

\begin{abstract}
The removal of uranium (U) onto nanoscale zero-valent iron particles has been studied for uranium-bearing mine water and synthetic uranyl solutions in the presence and absence of dissolved oxygen. The work has been conducted in order to investigate the differential nanoparticle corrosion behaviour and associated mechanisms of $U$ removal behaviour in conditions representative of near-surface and deep groundwater systems. Batch systems were analysed over a 28-day reaction period during which the liquid and nanoparticulate solids were periodically analysed to determine chemical evolution of the solutions and particulates. Analysis of aqueous samples using inductively coupled plasma mass spectrometry recorded near-total U removal after 1 hour of reaction in all systems studied. However, in the latter stages of the reaction (after 48 hours), significant rerelease of uranium was recorded for the mine water batch system with dissolved $\mathrm{O}_{2}$ present. In contrast, less than $2 \%$ uranium rerelease was recorded for the anoxic batch system. Concurrent analysis of extracted nanoparticle solids using X-ray diffraction recorded significantly slower corrosion of the nanoparticles in the anoxic batch system, with residual metallic iron maintained until after 28 days of reaction compared to only 7 days of reaction in systems with dissolved $\mathrm{O}_{2}$ present. Results provide clear evidence that the corrosion lifespan and associated $\mathrm{U}^{6+}$ removal efficacy of nanoscale zero-valent iron replace enhanced in the absence of dissolved oxygen.
\end{abstract}

\section{Introduction}

To date, a key environmental legacy of mankind's military and civil nuclear activities has been the release of uranium (U) into the natural environment. $U$ can exist in five oxidation states: $+2,+3,+4,+5$, and +6 . However, in the natural environment, the +4 and +6 valence states dominate. $\mathrm{U}^{4+}$ commonly exists in chemically reducing environments and typically forms chemical species of relatively low solubility [1]. In contrast, $\mathrm{U}^{6+}$ is predominant in oxidising environments and typically forms compounds of relatively high solubility [2]. Reduction of $\mathrm{U}^{6+}$ to $\mathrm{U}^{4+}$ has therefore been proposed as a suitable approach to $\mathrm{U}$ remediation.

In recent years, a wide range of electron donors have been demonstrated to chemically reduce $\mathrm{U}^{6+}$ including reduced iron, including magnetite, [3] ferrous hydroxides, [4] $\mathrm{Fe}^{2+}$ sorbed on hematite surfaces [5], and zero-valent iron [6]; microorganisms, including dissimilatory metalreducing bacteria [7] and sulphate reducing bacteria [8]; organic compounds, including acetate [9] and lactate [10]; and dissolved and solid sulphide species [11-16]. In contaminated sites the presence of competitive electron acceptors, toxic heavy metals, and/or unfavourable $\mathrm{pH} / \mathrm{Eh}$ conditions can significantly limit the suitability of many biotic methods for uranium remediation $[17,18]$. As a consequence, much focus has been applied in recent years on the use of chemical reducing agents, namely, zero-valent iron [19-28]. Recent work, investigating the removal of uranium in waste effluents [19] and mine water [22], has determined that the key role complexing agents, commonly found in natural waters, such as carbonate, phosphate, and sulphate, play on the long term removal of uranium onto nanoscale zero-valent iron. Results have provided clear evidence that such complexing agents (namely, carbonate) significantly enhance the relative stability of $\mathrm{U}^{6+}$, promoting $\mathrm{U}$ desorption from particle surfaces following an initial period of removal onto nanoscale zero-valent iron. The mechanism has been attributed to incomplete chemical reduction of surface-precipitated $\mathrm{U}^{6+}$, 
allowing $U$ rerelease during subsequent nanoparticle corrosion and the reformation of highly stable aqueous $U$ complexes. There accordingly exists a fundamental need to understand the reversible nature of $U$ removal in complex and/or natural waters using iron-based materials, specifically the link between nanoparticle corrosion and $U$ desorption. The current work has therefore been established to contrast the sorption-desorption behaviour of $U$ onto nanoscale zerovalent iron in natural waters containing dissolved oxygen (and dissolved oxygen recharge), that is, the vadose zone, with waters where dissolved oxygen is only available in trace levels, that is, the phreatic zone.

\section{Materials and Methods}

2.1. Experimental Procedure. Four $500 \mathrm{~mL}$ Schott Duran jars were each filled with $400 \mathrm{~mL}$ of the U-bearing mine water. Further four jars were filled with $400 \mathrm{~mL}$ of uranyl solution at $0.5 \mathrm{ppm} \mathrm{U}$, with the solution $\mathrm{pH}$ adjusted to 9.52 using $0.01 \mathrm{M} \mathrm{NaOH}$. The addition of $\mathrm{NaOH}$ was performed slowly, dropwise, to avoid the formation of hydroxocarbonyl complexes. Two of the mine water solutions and two of the uranyl solutions were then purged with oxygen-free $\mathrm{N}_{2 \text { (g) }}(>99.998 \%)$ at $1 \mathrm{~L} \mathrm{~m}^{-1}$ for 30 minutes to reduce the content of $\mathrm{O}_{2(\mathrm{~g})}$ to $<0.1 \mathrm{ppm}$ and left in a Saffron Scientific glovebox for 7 days to equilibrate. The glovebox atmosphere consisted of $\mathrm{N}_{2} / \mathrm{H}_{2}(95: 5)$ and a Coy Laboratory "StakPak" palladium catalyst was used to catalyse the removal of $\mathrm{O}_{2(\mathrm{~g})}$, via reaction with $\mathrm{H}_{2(\mathrm{~g})}$, producing $\mathrm{H}_{2} \mathrm{O}_{(\mathrm{l})}$. The two remaining mine water solutions were stored on the benchtop. To two of the mine water solutions (one oxic and one anoxic) and two of the uranyl solutions (one oxic and one anoxic), $0.2{\mathrm{~g}\left(0.5 \mathrm{~g} \mathrm{~L}^{-1}\right) \text { of nano-Fe }}^{0}$ was added. The two remaining mine water solutions (oxic and anoxic) and the two uranyl solutions (oxic and anoxic) were run as nanoparticle-free control systems. In each case, the nano- $\mathrm{Fe}^{0}$ was suspended in $2 \mathrm{~mL}$ of ethanol and dispersed by sonification for 30 seconds. During the experiment, the glovebox containing the anoxic batch systems was purged with $\mathrm{N}_{2} / \mathrm{H}_{2}(95: 5)$ gas at 0.5 bar for 5 minutes every 24 hours.

2.2. Sampling Methods. Each system was sampled at $0 \mathrm{~h}, 1 \mathrm{~h}$, $2 \mathrm{~h}, 4 \mathrm{~h}, 24 \mathrm{~h}, 48 \mathrm{~h}, 7 \mathrm{~d}, 14 \mathrm{~d}$, and $28 \mathrm{~d}$. Prior to sampling, the jars were gently agitated to ensure homogeneity and $\mathrm{pH}$ and Eh measurements were taken using a Hanna Instruments meter (model HI 8424) with a combination gel electrode $\mathrm{pH}$ probe and a platinum ORP electrode, respectively. Dissolved oxygen (DO) measurements were taken using a Jenway 970 $\mathrm{DO}_{2}$ meter. Aliquots of $10 \mathrm{~mL}$ were taken from each jar and centrifuged using a Hamilton Bell Vanguard V6500 desktop centrifuge at $6500 \mathrm{rpm}$ for 30 seconds to separate the liquid and solid phases. The liquid was decanted, filtered through a $0.22 \mu \mathrm{m}$ cellulose acetate filter, and then prepared for inductively coupled plasma atomic emission spectrometry (ICP-AES) and inductively coupled plasma mass spectrometry (ICP-MS). The solid was prepared for Xday diffraction (XRD) and X-ray photoelectron spectroscopy (XPS) by sequential rinsing in $3 \mathrm{~mL}$ each of Milli-Q water, ethanol, and then acetone, with the resultant suspension pipetted onto a glass optical microscope slide and aluminium stub, respectively.

2.3. Nanoparticle Synthesis. Iron nanoparticles were synthesised following the method first described by Wang and Zhang [29] using sodium borohydride to reduce ferrous iron to a metallic state. $1.35 \mathrm{~g}$ of $\mathrm{FeCl}_{3} \cdot 6 \mathrm{H}_{2} \mathrm{O}$ was dissolved in $50 \mathrm{~mL}$ of Milli-Q water $(>18.2 \mathrm{M} \Omega \mathrm{cm})$ and then a $4 \mathrm{M}$ $\mathrm{NaOH}$ solution was used to adjust the solution $\mathrm{pH}$ to 6.8 . The addition of $\mathrm{NaOH}$ was performed slowly, dropwise, to avoid the formation of hydroxocarbonyl complexes. The salts were reduced to metallic nanoparticles by the addition of $2.0 \mathrm{~g}$ of $\mathrm{NaBH}_{4}$. The nanoparticle product was then isolated through centrifugation and sequentially washed with water, ethanol, and acetone $(20 \mathrm{~mL}$ of each). The nanoparticles were dried in a dessicator under low vacuum (approx. $10^{-2}$ mbar) for 48 hours and then stored in the oxygen-free nitrogen environment of a Saffron Scientific glovebox until required.

2.4. ICP-AES Preparation. The liquid samples were prepared for ICP-AES analysis by a 10 -time dilution in $1 \%$ nitric acid (analytical quality concentrated $\mathrm{HNO}_{3}$ in Milli-Q water). Blanks and standards for analysis were also prepared in $1 \%$ nitric acid, with Fe standards of $0.1,0.25,0.5,1,2.5,5$, and $10 \mathrm{ppm}$. A Jobin Yvon Ultima ICP-AES (sequential spectrometer) fitted with a cyclone spray chamber and a Burgener Teflon Mira Mist Nebulizer was used. The Fe concentration was measured using the emission line at $259.94 \mathrm{~nm}$.

2.5. ICP-MS Preparation. Samples were prepared for ICP-MS analysis by a 10 -time dilution in $1 \%$ nitric acid (analytical quality concentrated $\mathrm{HNO}_{3}$ in Milli-Q water). Blanks and uranium standards at $0.1,0.5,1,5$, and $10 \mathrm{ppb}$ were also prepared in $1 \%$ nitric acid (analytical quality concentrated $\mathrm{HNO}_{3}$ in Milli-Q water). An internal Bi standard of $10 \mathrm{ppb}$ was added to blanks, standards, and samples. The ICP-MS instrument used was Thermo Elemental PQ3.

2.6. XPS. Solid samples were analysed at $<5 \times 10^{-8} \mathrm{mbar}$ in a Thermo Fisher Scientific Escascope equipped with a dual anode $\mathrm{X}$-ray source $\left(\mathrm{Al}_{\mathrm{K} \alpha} 1486.6 \mathrm{eV}\right.$ and $\left.\mathrm{Mg}_{\mathrm{K} \alpha} 1253.6 \mathrm{eV}\right)$. $\mathrm{Al}_{\mathrm{K} \alpha}$ radiation was used at $400 \mathrm{~W}(15 \mathrm{kV}, 23 \mathrm{~mA})$. High resolution scans were acquired using a $30 \mathrm{eV}$ pass energy and $200 \mathrm{~ms}$ dwell times. Following the acquisition of "wide" spectra over a wide binding energy range, the regions containing the $\mathrm{C}$ and $\mathrm{U}$ peaks were scanned at a higher energy resolution. Data analysis was carried out using Pisces software (Dayta Systems Ltd.) with binding energy values of the recorded lines referenced to the adventitious hydrocarbon Cls peak at $284.8 \mathrm{eV}$.

2.7. XRD. A Phillips Xpert Pro diffractometer with a $\mathrm{Cu}_{\mathrm{K} \alpha}$ radiation source $(\lambda=1.5406 \AA)$ was used for XRD analysis (generator voltage of $40 \mathrm{keV}$; tube current of $30 \mathrm{~mA}$ ). XRD spectra were acquired between $2 \theta$ angles of $0-90^{\circ}$, with a step size of $0.02^{\circ}$ and a $2 \mathrm{~s}$ dwell time. 
TABLE 1: Bulk and surface properties of the nano- $\mathrm{Fe}^{0}$ used in the current work.

\begin{tabular}{lcc}
\hline Parameter & & Nano- $\mathrm{Fe}^{0}$ \\
\hline \multirow{2}{*}{ Particle size distribution (\%) } & $0-50 \mathrm{~nm}$ & 85 \\
& $50-100 \mathrm{~nm}$ & 8 \\
& $>100 \mathrm{~nm}$ & 7 \\
\hline Crystallinity & & $\begin{array}{c}\text { Amorphous } \\
(\alpha-\mathrm{Fe})\end{array}$ \\
\hline Oxide thickness $(\mathrm{nm})$ & & $3-4$ \\
\hline Surface area $\left(\mathrm{m}^{2} \mathrm{~g}^{-1}\right)$ & $\mathrm{Fe}$ & 14.8 \\
\hline & $\mathrm{O}$ & 30.5 \\
Surface composition $(\%)$ & $\mathrm{C}$ & 32.1 \\
& $\mathrm{~B}$ & 14.5 \\
\hline Surface stoichiometry & $\left(\mathrm{Fe}^{0} / \mathrm{Fe}^{2+}+\mathrm{Fe}^{3+}\right)$ & 0.02 \\
& $\mathrm{Fe}^{2+} / \mathrm{Fe}^{3+}$ & 0.38 \\
\hline
\end{tabular}

Note: a significant proportion of the carbon detected is likely to be adventitious carbon.

\section{Results}

3.1. Preliminary Characterisation of the Nanoparticles. Preliminary characterisation of the nano- $\mathrm{Fe}^{0}$ was performed using Brunauer, Emmett, and Teller (BET) surface area analysis, transmission electron microscopy (TEM), XRD, and XPS. BET analysis determined that the starting surface area of the nano- $\mathrm{Fe}^{0}$ was $14.8 \mathrm{~m}^{2} \mathrm{~g}^{-1}$. TEM analysis determined that the nano- $\mathrm{Fe}^{0}$ were roughly spherical, with an approximate size range of $20-100 \mathrm{~nm}$ and an average diameter of $34 \mathrm{~nm}$. The density contrast between the $\mathrm{Fe}^{0}$ core and oxide shell in the nano- $\mathrm{Fe}^{0}$ was identified; however, the material was recorded as relatively amorphous with no clear grain structure. Individual particles were recorded as aggregated into chains and rings, attributed to the magnetic properties of the $\mathrm{Fe}^{0}$ cores. XRD analysis recorded a broad diffraction peak at $44.9^{\circ} 2 \theta$ and other low intensity peaks at $65^{\circ}$ and $82^{\circ}$ $2 \theta$, implying the presence of amorphous $\mathrm{Fe}^{0}$. XPS analysis confirmed the presence of a mixed valent $\left(\mathrm{Fe}^{2+} / \mathrm{Fe}^{3+}\right)$ oxide at the surface of the material. The results are summarised in Table 1.

\subsection{Preliminary Characterisation of the U-Bearing Mine} Water. Prior to nanoparticle addition, the U-bearing mine water was characterised using ICP-AES ( $\mathrm{Fe}, \mathrm{Mg}, \mathrm{Cu}$, and Mo), ICP-MS (U), volumetric titration $\left(\mathrm{HCO}_{3}{ }^{-}, \mathrm{NO}_{3}{ }^{-}\right.$, and $\mathrm{PO}_{4}{ }^{3-}$ ), and gravimetry $\left(\mathrm{SO}_{4}{ }^{2-}\right.$ ) with supplementary $\mathrm{Eh}$, $\mathrm{pH}$, and $\mathrm{DO}$ measurements. The analysis indicated that $\mathrm{HCO}_{3}{ }^{-}$, well documented to form uranyl complexes of high thermodynamic stability [30], was the most common ligand species present, with a concentration of approximately 974 ppm (Table 2).

3.3. The Effect of Inert Gas Sparging. Following $\mathrm{N}_{2}$ gas sparging a decrease in solution $\mathrm{Eh}$, from $65 \mathrm{mV}$ to $-49 \mathrm{mV}$, was recorded concurrent with a significant decrease in DO, from $8.93 \mathrm{ppm}$ to $0.09 \mathrm{ppm}$, and ascribed to the expulsion
TABLE 2: Concentrations of notable chemical species present in the mine water, analysed by ICP-MS (U), ICP-AES (Fe, $\mathrm{Mg}, \mathrm{Cu}$, and $\mathrm{Mo})$, volumetric titration $\left(\mathrm{HCO}_{3}{ }^{-}, \mathrm{NO}_{3}{ }^{-}\right.$, and $\left.\mathrm{PO}_{4}{ }^{3-}\right)$, and gravimetry $\left(\mathrm{SO}_{4}{ }^{2-}\right)$ along with the recorded $\mathrm{Eh}, \mathrm{pH}$, and $\mathrm{DO}$.

\begin{tabular}{lc}
\hline Chemical species & Concentration $(\mathrm{ppm})$ \\
\hline Cations & \\
$\mathrm{Cu}$ & 0.044 \\
$\mathrm{Fe}$ & 0.021 \\
$\mathrm{Mg}$ & 12.11 \\
$\mathrm{Mo}$ & 0.21 \\
$\mathrm{U}$ & 1.41 \\
Anions & \\
$\mathrm{HCO}_{3}{ }^{-}$ & 974.42 \\
$\mathrm{NO}_{3}{ }^{-}$ & 18.53 \\
$\mathrm{PO}_{4}{ }^{3-}$ & 0.15 \\
$\mathrm{SO}_{4}{ }^{2-}$ & 0.51 \\
Solution conditions & \\
$\mathrm{DO}(\mathrm{ppm})$ & 8.84 \\
$\mathrm{Eh}(\mathrm{mV})$ & 65 \\
$\mathrm{pH}$ & 9.29 \\
\hline
\end{tabular}

of DO from the mine water. An increase in solution $\mathrm{pH}$, from 9.29 to 9.52 , was also recorded. This is a common phenomenon reported for carbonate-rich solutions during inert gas sparging and attributed to the expulsion of dissolved $\mathrm{CO}_{2}$, resulting in the hydrolysis of $\mathrm{HCO}_{3}{ }^{-}$(in the form of $\mathrm{NaHCO}_{3}$ ) and the formation of $\mathrm{OH}^{-}$[31-33].

3.4. Changes in $D O / E h / p H$. Following the addition of the nanoparticles a shift to chemically reducing Eh and near-zero DO was recorded within 15 minutes of reaction for all batch systems (Figure 1). An accompanying increase in system $\mathrm{pH}$ was also recorded in all systems (Figure 1). For the oxic batch systems, in the early stages of reaction ( $<15$ minutes), the predominant mechanism of nano- $\mathrm{Fe}^{0}$ corrosion is considered to have been through reaction with $\mathrm{H}^{+}$via the consumption of DO (see (1) and (2)). For the anoxic batch systems (and the oxic batch systems following total DO consumption) the absence of DO dictates that corrosion could only proceed through the direct reaction (hydrolysis) with water (see (3) and (4)). The slower $\mathrm{pH} / \mathrm{Eh}$ change recorded for the anoxic batch systems in the current work is therefore ascribed to the slower reaction kinetics of nano- $\mathrm{Fe}^{0}$ in the absence of DO:

$$
\begin{array}{lc}
2 \mathrm{Fe}^{0}+4 \mathrm{H}^{+}+\mathrm{O}_{2} \longrightarrow 2 \mathrm{Fe}^{2+}+2 \mathrm{H}_{2} \mathrm{O} & E^{0}=+1.67 \mathrm{~V} \\
2 \mathrm{Fe}^{2+}+2 \mathrm{H}^{+}+\frac{1}{2} \mathrm{O}_{2} \longrightarrow 2 \mathrm{Fe}^{3+}+\mathrm{H}_{2} \mathrm{O} & E^{0}=+0.46 \mathrm{~V} \\
\mathrm{Fe}^{0}+2 \mathrm{H}_{2} \mathrm{O}_{(\mathrm{l})} \longrightarrow \mathrm{Fe}^{2+}+\mathrm{H}_{2}+2 \mathrm{OH}^{-} & E^{0}=-0.39 \mathrm{~V}
\end{array}
$$

$2 \mathrm{Fe}^{2+}+2 \mathrm{H}_{2} \mathrm{O} \longrightarrow 2 \mathrm{Fe}^{3+}+\mathrm{H}_{2}+2 \mathrm{OH}^{-} \quad E^{0}=-1.60 \mathrm{~V}$ 

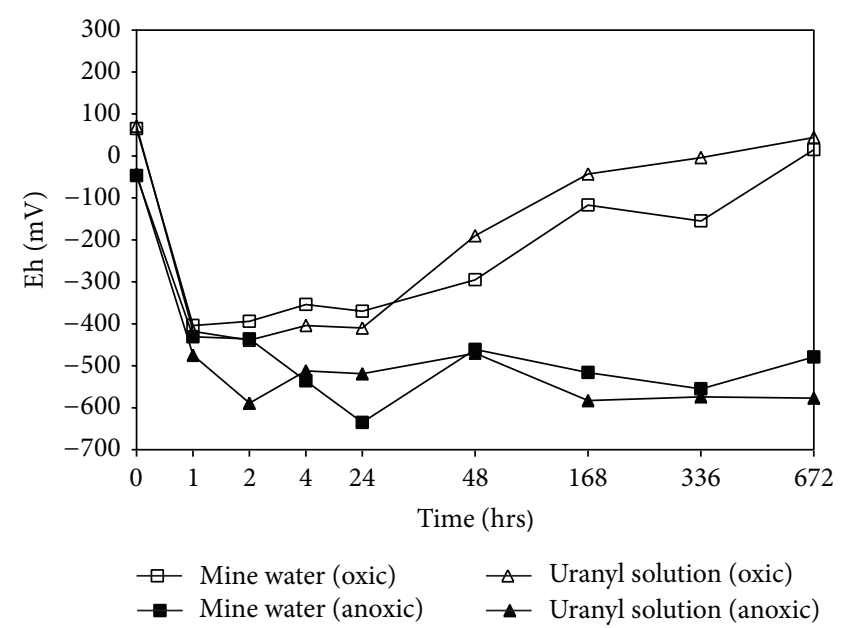

(a)

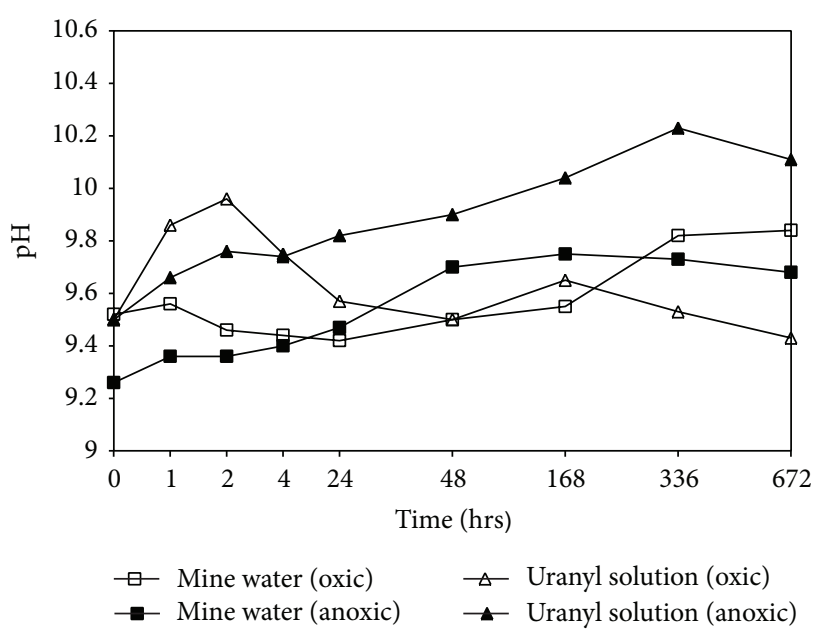

(b)

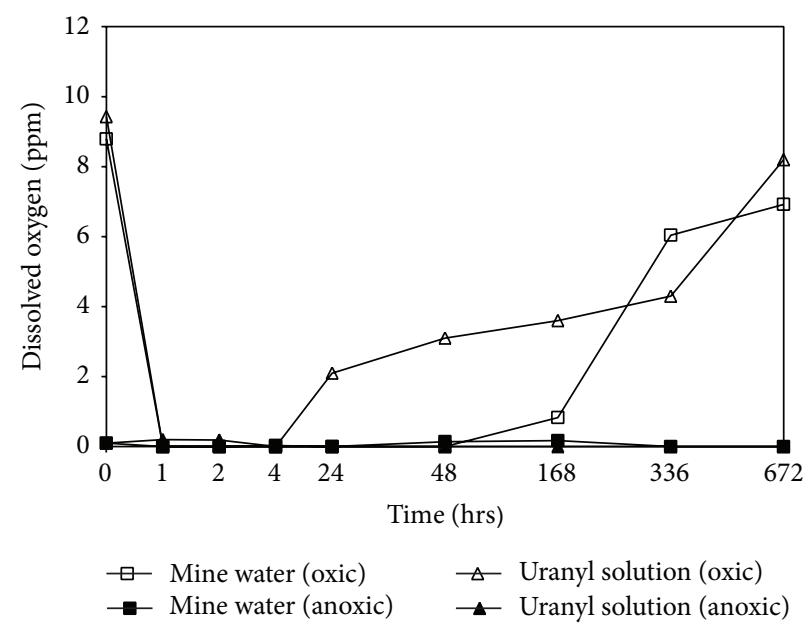

(c)

Figure 1: (a) Eh (mV) as a function of reaction time (0-672 hrs). The control (nanoparticle-free) solutions (not shown) recorded a variation of $<10 \mathrm{mV}$ in all systems; (b) $\mathrm{pH}$ as a function of reaction time (0-672 hrs). The control (nanoparticle-free) solution (not shown) recorded a variation of $<0.2 \mathrm{pH}$ units in all systems; (c) dissolved oxygen ( $\mathrm{ppm}$ ) as a function of reaction time (0-672 hrs). The control (nanoparticle-free) solution (not shown) recorded a variation of $<0.05 \mathrm{ppm}$ units in all systems.

In addition, fast $\mathrm{pH} /$ Eh changes were recorded for the uranyl solutions compared to the mine water batch systems. This is attributed to the lack of major ions in the former systems to buffer the aforementioned geochemical perturbation imbued by nanoparticle corrosion.

After 4 hours of reaction, a recovery in DO and Eh was recorded for the oxic batch systems only. In contrast, Eh and $\mathrm{DO}$ were maintained as less than $-430 \mathrm{mV}$ and $<0.2 \mathrm{ppm} \mathrm{O}_{2}$, respectively, for the entire 28-day reaction period for both anoxic batch systems. Near-zero DO $(<0.1 \mathrm{ppm})$ was recorded for the anoxic (nanoparticle-free) batch system for the entire 28-day reaction period. This provides clear evidence of minimal oxygen ingress into the anoxic batch systems.

3.5. Changes in Aqueous $U$ and Fe Concentration. Analysis of liquid samples using ICP-MS recorded rapid and near-total U removal in all systems treated using nano-Fe ${ }^{0}$ (Figure 2) with removal of $>99 \% \mathrm{U}_{(\mathrm{aq})}$ recorded after 1 hour in all systems and maintained until 48 hours of reaction. Onwards from 48 hours a gradual increase in $\mathrm{U}_{(\mathrm{aq})}$ concentration was recorded for the oxic mine water batch system (Figure 2). In contrast, no appreciable $U$ rerelease was recorded for the anoxic mine water and the uranyl batch systems in both oxic and anoxic conditions. This is attributed to the presence of complexing agents (namely, carbonate) in the mine water, allowing the reformation of dissolved U-complexes concurrent with nanoparticle corrosion during the ingress of atmospheric gases into the batch systems as previously observed [22]. As reported by Crane et al., [22] it is likely that chemical reduction of aqueous $\mathrm{U}^{6+}$ to solid $\mathrm{U}^{4+}$ (as $\mathrm{UO}_{2}$ ) occurred for all batch treatment systems during the initial stage of $U$ sorption onto the nano- $\mathrm{Fe}^{0}$. However, for the mine water solutions containing dissolved oxygen, oxidation back to aqueous $\mathrm{U}^{6+}$ is likely to have occurred due to a combination of (i) the increased availability of dissolved oxygen and (ii) 


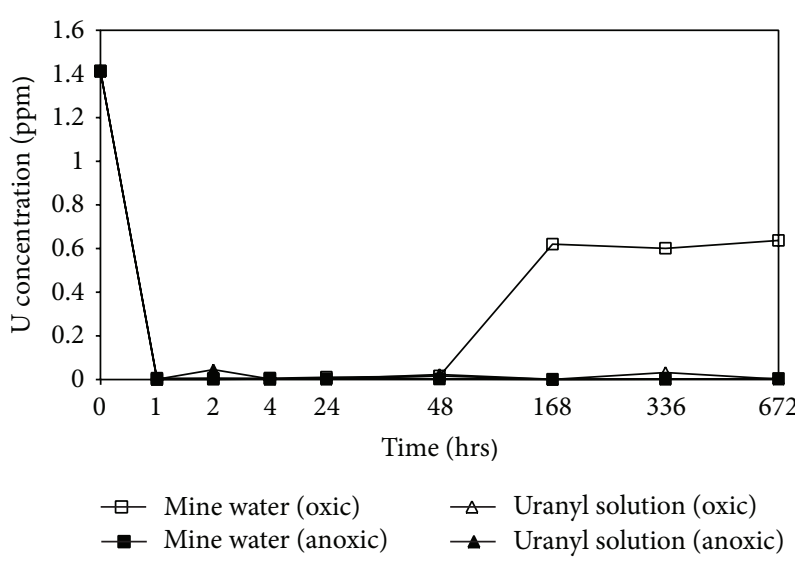

(a)

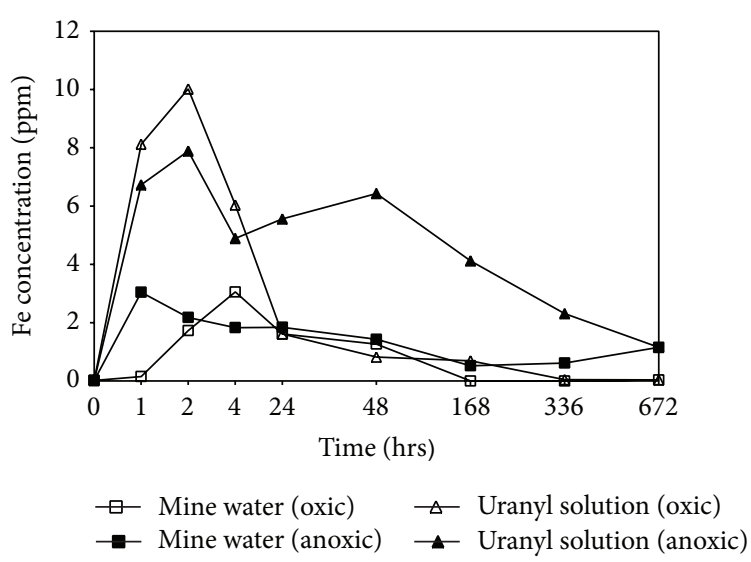

(b)

FIGURE 2: (a) Aqueous uranium concentration ( $\mathrm{ppm}$ ) as a function of reaction time (0-672 hrs). The control (nanoparticle-free) solutions (not shown) recorded a variation of $<0.01 \mathrm{ppm}$ from the starting concentration in all systems; (b) aqueous iron concentration (ppm) as a function of reaction time ( $0-672 \mathrm{hrs})$. The control (nanoparticle-free) solutions (not shown) recorded a variation of $<0.02 \mathrm{ppm}$ from the starting concentration in all systems.

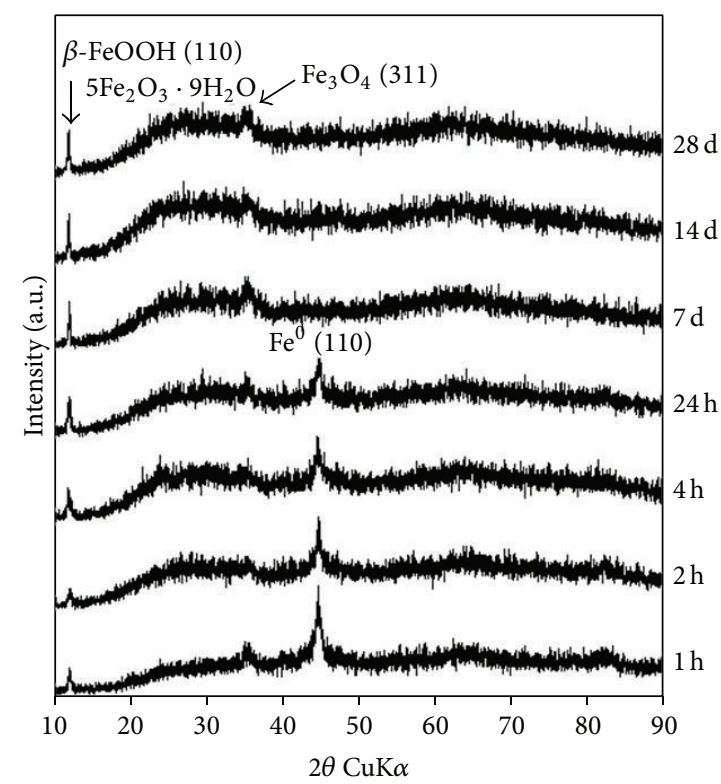

(a)

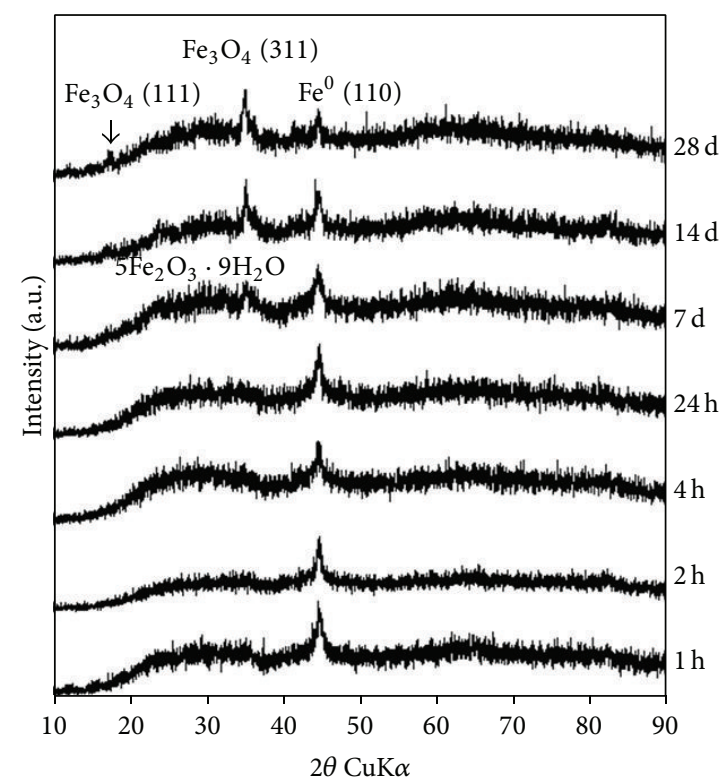

(b)

FIGURE 3: X-ray diffraction (XRD) spectra (for the range of $10-90^{\circ} 2 \theta$ ) recorded for the oxic (a) and anoxic (b) mine water batch systems after reaction times of $1 \mathrm{~h}, 2 \mathrm{~h}, 4 \mathrm{~h}, 24 \mathrm{~h}, 7 \mathrm{~d}, 14 \mathrm{~d}$, and $28 \mathrm{~d}$.

the enhanced solubility of $U$ in the presence of complexing agents, such as carbonate.

Analysis of liquid samples using ICP-AES recorded an increase in $\mathrm{Fe}_{(\mathrm{aq})}$ following the addition of the nanoparticles, with maximum $\mathrm{Fe}_{(\mathrm{aq})}$ concentrations recorded in all systems within the first 48 hours of reaction and attributed to the rapid corrosion of nanoparticulate surfaces. The greatest $\mathrm{Fe}_{(\mathrm{aq})}$ concentrations were recorded for the uranyl solutions and ascribed to the lower ionic concentration compared to the mine water.

\subsection{Analysis of Reacted Nanoparticulate Solids}

3.6.1. X-Ray Diffraction. XRD was used to determine the bulk crystallinity and composition of nano- $\mathrm{Fe}^{0}$ solids extracted from both oxic and anoxic batch systems at periodic intervals during the experiment (Figure 3). A transition from $\mathrm{Fe}^{0}$, with peaks centred at $44.6,65.6$, and $82.6^{\circ} 2 \theta$ (lattice reflections: $\mathrm{Fe}(110), \mathrm{Fe}(200)$, and $\mathrm{Fe}(211)$, resp.), to a mixture of akaganéite $(\beta-\mathrm{FeOOH})$, ferrihydrite $\left(5 \mathrm{Fe}_{2} \mathrm{O}_{3} \cdot 9 \mathrm{H}_{2} \mathrm{O}\right)$, and magnetite $\left(\mathrm{Fe}_{3} \mathrm{O}_{4}\right)$ was recorded for both oxic and anoxic batch systems. Total $\mathrm{Fe}^{0}$ conversion was, however, not recorded for 

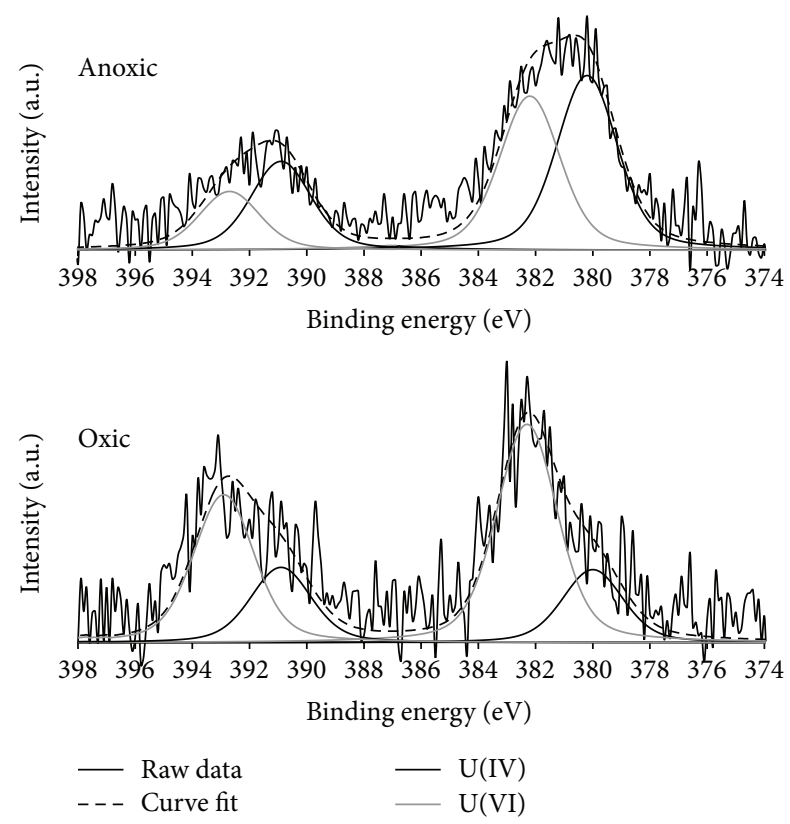

FIGURE 4: Curve fitted XPS U 4f photoelectron peaks acquired after 24 hours of reaction for mine water batch systems treated with nano$\mathrm{Fe}^{0}$.

the anoxic system with residual $\mathrm{Fe}^{0}$ present after 28 days of reaction compared to full conversion exhibited by the oxic batch system after 7 days of reaction. This is ascribed to the slower corrosion of nano- $\mathrm{Fe}^{0}$ in the absence of $\mathrm{DO}$ as discussed above.

The formation of ferrihydrite and magnetite was not unexpected, given that both species are common $\mathrm{Fe}^{0}$ corrosion products in near-neutral to alkaline solutions [3438]. The presence of chloride ions (which are necessary for akaganéite formation) was likely to have been provided by the dissolution of $\mathrm{FeCl}_{2}$, present in the nano- $\mathrm{Fe}^{0}$ due to incomplete conversion of $\mathrm{FeCl}_{2}$ to $\mathrm{Fe}^{0}$ during the nano- $\mathrm{Fe}^{0}$ synthesis. In the latter stages of the reaction ( $>7$ days) the akaganéite peak was recorded to shift by approximately $-0.5^{\circ}$ $2 \theta$, suggesting an increase in the lattice parameter of the material. This was attributed to cationic substitution of a larger ion, such as $\mathrm{Ca}^{2+}(0.212 \mathrm{~nm}$ compared to $0.166 \mathrm{~nm})$, into the lattice structure [39].

3.6.2. X-Ray Photoelectron Spectroscopy. X-ray photoelectron spectroscopy (XPS) was used to determine the surface chemistry of extracted particulates including any sorbed species extracted from the oxic and anoxic batch systems at regular intervals throughout the experiment (Figure 4). Curve fitting of recorded $\mathrm{Fe} 2 \mathrm{p}_{3 / 2}$ photoelectron peaks (not shown) determined a decrease in the $\mathrm{Fe}^{2+} / \mathrm{Fe}^{3+}$ ratio throughout the reaction period, ascribed to the oxidation of the nanoparticle surfaces. This occurred most rapidly during the initial stages of the reaction, with oxic and anoxic systems recording a shift in $\mathrm{Fe}^{2+} / \mathrm{Fe}^{3+}$ ratio to 0.23 and 0.32 , respectively, after 1 hour of reaction. The higher proportion of $\mathrm{Fe}^{3+}$ in the oxic system is attributed to a greater concentration of DO at the start of the reaction. Following this initial and rapid oxidation phase, a more gradual decrease in the $\mathrm{Fe}^{2+} / \mathrm{Fe}^{3+}$ ratio was recorded in all oxic systems to minima of 0.11 after 28 days of reaction. In contrast, no appreciable change was recorded for all anoxic systems, indicating that minimal nano- $\mathrm{Fe}^{0}$ oxidation had occurred.

XPS data recorded from the samples of extracted particulates failed to record detectable peaks in the $\mathrm{U} 4 \mathrm{f}$ binding energy region of the recorded photoelectron spectra in all the reacted samples, even during the initial period of maximum $\mathrm{U}$ removal. This was not unexpected, given the small amount of $\mathrm{U}$ in each system $\left(1413 \mu \mathrm{L}^{-1}\right)$ relative to the large surface area presented by the nanoparticles $\left(14.8 \mathrm{~m}^{2} \mathrm{~g}^{-1}\right)$. U $4 \mathrm{f}$ photoelectron peaks were detected for both oxic and anoxic mine water samples after 4 hours of reaction. Curve fitting, following the method of Scott et al., determined that $U$ present was in a partially reduced state for both systems with a $\mathrm{U}^{4+} / \mathrm{U}^{6+}$ ratio of 0.34 and 1.13 recorded for the oxic and anoxic system, respectively. Greater proportion of $\mathrm{U}^{4+}$ relative to $\mathrm{U}^{6+}$ recorded for the anoxic batch system is attributed to enhanced chemical reduction of $U$ in low oxygen conditions. This is likely to be due to the significantly lower (and sustained) Eh conditions imbued by the nano- $\mathrm{Fe}^{0}$ in the low oxygen environment, where $\mathrm{Fe}^{0}$ is maintained throughout the 28 -day reaction period (see Section 3.6.1). In contrast $\mathrm{Fe}^{0}$ was recorded to be oxidised to (oxy)hydroxide species more rapidly in the batch systems containing dissolved oxygen, which would have resulted in lower chemical reduction of $\mathrm{U}^{6+}$ to $\mathrm{U}^{4+}$.

\section{Discussion}

Nano- $\mathrm{Fe}^{0}$ have been tested in the current work for the removal of $U$ from mine water batch systems in both dissolved oxygen containing (starting DO $\sim 9.5 \mathrm{ppm}$ and batch systems handled and stored in the open laboratory) and anoxic (starting DO $<0.1 \mathrm{ppm}$ and batch systems handled and stored in a nitrogen-filled glovebox) batch systems. Nano- $\mathrm{Fe}^{0}$ were documented as highly effective for the rapid removal of $U$ despite the high concentration of complexing agents present in the mine water, namely, bicarbonate at 974 ppm, with near-total U removal recorded after 1 hour of reaction for all systems studied. Limited long term $U$ removal, however, was recorded for the batch systems with DO present, with significant $U$ rerelease recorded within 7 days of nano- $\mathrm{Fe}^{0}$ application. In contrast, no appreciable $\mathrm{U}$ rerelease was recorded for the anoxic mine water batch system. XRD analysis of nano- $\mathrm{Fe}^{0}$ extracted from both oxic and anoxic systems determined that whilst total conversion of nano- $\mathrm{Fe}^{0}$ to (oxy)hydroxide corrosion products had occurred in the oxic systems, $\mathrm{Fe}^{0}$ was maintained in the anoxic systems. Concurrent XPS analysis determined that sorbed $\mathrm{U}$ was present in a partially reduced state in both oxic and anoxic systems; however, greater chemical reduction 


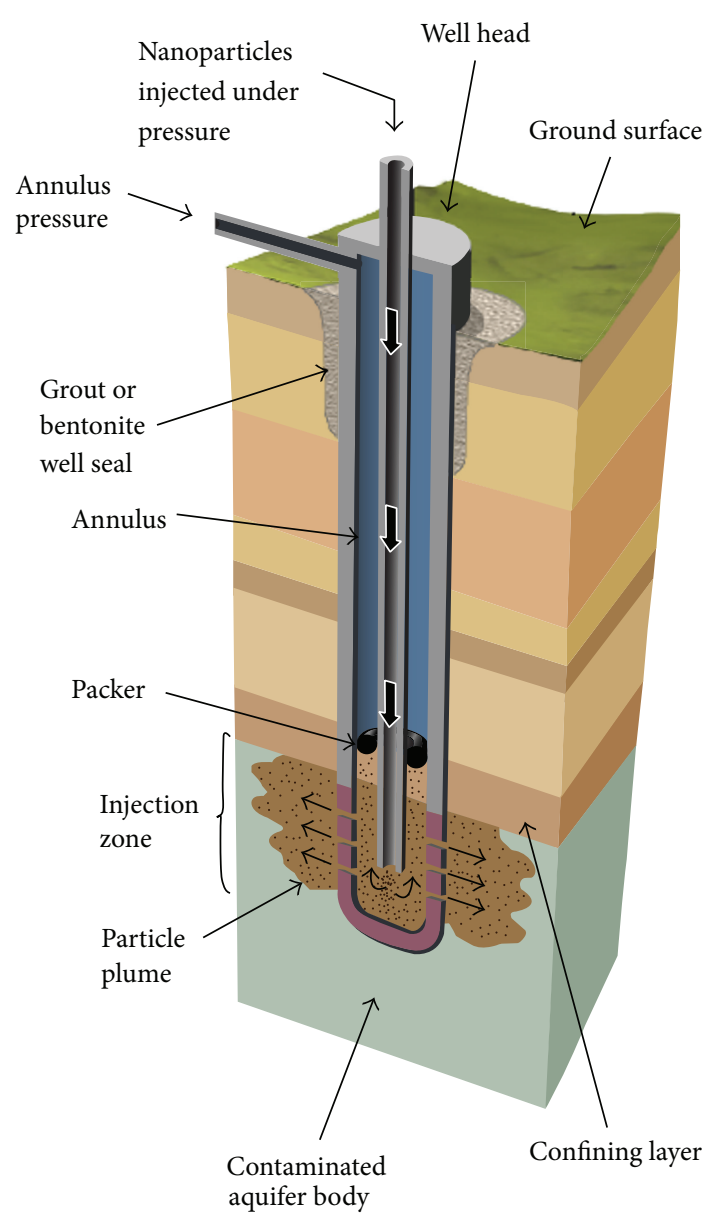

(a) Nanoparticle injection well

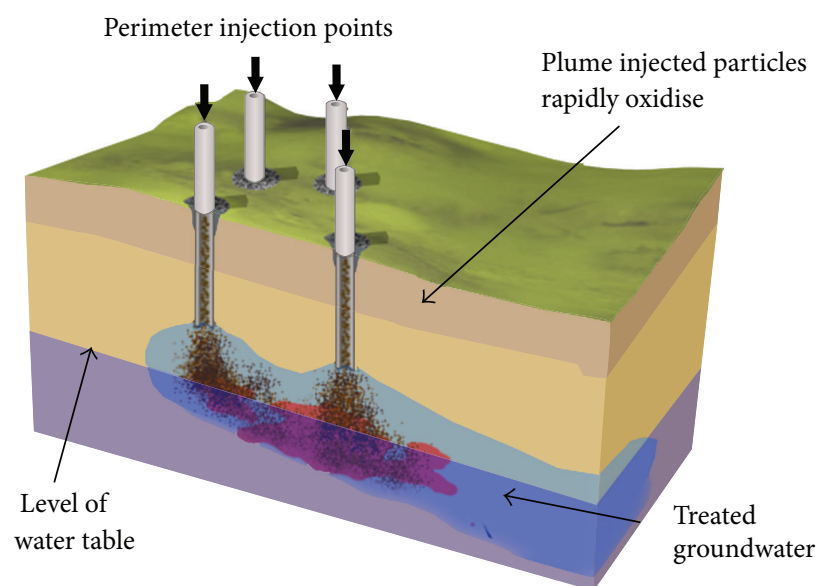

Metal and metalloid contaminants remobilise shortly after nanoparticle injection due to the abundant supply of oxygen

(b) Vadose (oxic) zone treatment

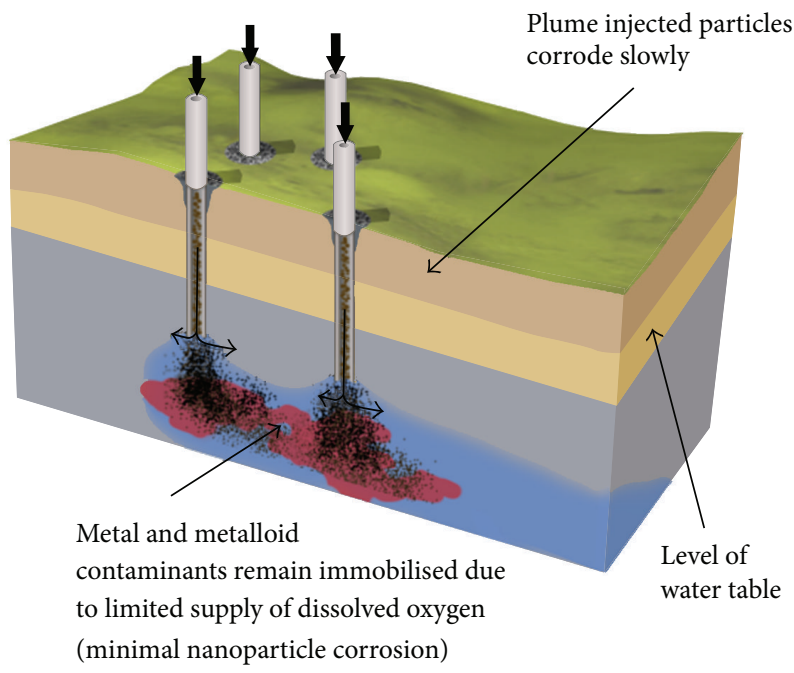

(c) Phreatic (anoxic) zone treatment

FIGURE 5: Schematic diagram of the following: (a) a typical nanoparticle injection well: the technology is very similar to that used for injection of $\mathrm{CO}_{2}$ into subterranean storage reservoirs; (b) in situ vadose (oxic) zone treatment of metal and metalloid aqueous contaminant species using nanoscale zero-valent iron particles: contaminants remobilise shortly after nanoparticle injection due to the abundant supply of dissolved oxygen; and (c) in situ phreatic (anoxic) zone treatment of metal and metalloid aqueous contaminant species using nanoscale zero-valent iron particles: contaminants remain immobilised due to the limited supply of dissolved oxygen.

was recorded for the anoxic systems. The mechanism of $\mathrm{U}$ rerelease in the oxic systems is therefore attributed to the incomplete chemical reduction of surface-precipitated $U$ (from soluble $\mathrm{U}^{6+}$ to insoluble $\mathrm{U}^{4+}$ ) within the mine water samples, allowing the rerelease of $\mathrm{U}^{6+}$ during the ingress of DO back into batch systems, and the reformation of highly stable (nominally carbonate) aqueous U-complexes. This was not recorded for the anoxic systems because the absence of $\mathrm{DO}$ allowed $\mathrm{Fe}^{0}$ to be maintained (and associated strongly chemically reducing conditions) throughout the 28day reaction period. Figure 5 displays a schematic diagram of this hypothesis applied for the in situ treatment of metal and metalloid aqueous contaminant species using nanoscale zero-valent iron particles.

\section{Conclusions}

The rerelease of metal and metalloid contaminant species following a period of "apparent remediation" is a key engineering challenge which may limit the development of nano$\mathrm{Fe}^{0}$ as a new technology for mine water treatment. The current work has provided clear evidence that nano- $\mathrm{Fe}^{0}$ is only appropriate for the in situ treatment of $\mathrm{U}$ in surface and/or vadose zone waters if extremely robust secondary method(s) are applied to prevent DO ingress into the contaminant treatment zone. Example materials include impermeable geomembranes and bentonite. For the in situ treatment of anoxic mine water, it is shown that $U$ removal can be maintained on a long term or even quasi-permanent basis 
if there is sufficiently low DO flux to maintain the strongly chemically reducing groundwater conditions imbued by the nano- $\mathrm{Fe}^{0}$.

Further work is required to examine the reversible nature of metal and metalloid remediation in complex and/or natural waters using nano- $\mathrm{Fe}^{0}$. This will provide validation of the technology for sites where assurance of medium to long term immobilisation of contaminants is required.

\section{Conflict of Interests}

The authors declare that there is no conflict of interests regarding the publication of this paper.

\section{Acknowledgments}

The authors would like to thank the National Company Uranium (Romania) for providing mine water samples for the current work. They would also like to thank scientists from the National Institute for Metals and Radioactive Resources, Bucharest, Romania, for help with arranging delivery of the mine water samples to the University of Bristol. The work was funded by the Engineering and Physical Sciences Research Council.

\section{References}

[1] D. Langmuir, "Uranium solution-mineral equilibria at low temperatures with applications to sedimentary ore deposits," Geochimica et Cosmochimica Acta, vol. 42, no. 6, pp. 547-569, 1978.

[2] R. Guillaumont, T. Fanghanel, J. Fuger et al., Update on the Chemical Thermodynamics of Uranium, Neptunium, and Plutoniumed, Elsevier, Amsterdam, The Netherlands, 2nd edition, 2003.

[3] T. B. Scott, G. C. Allen, P. J. Heard, and M. G. Randell, "Reduction of U(VI) to U(IV) on the surface of magnetite," Geochimica et Cosmochimica Acta, vol. 69, no. 24, pp. 56395646, 2005.

[4] E. J. O’Loughlin, S. D. Kelly, R. E. Cook, R. Csencsits, and K. M. Kemner, "Reduction of uranium(VI) by mixed iron(II)/iron(III) hydroxide (green rust): formation of $\mathrm{UO}_{2}$ nanoparticles," Environmental Science and Technology, vol. 37, no. 4, pp. 721-727, 2003.

[5] E. Liger, L. Charlet, and P. Van Cappellen, "Surface catalysis of uranium(VI) reduction by iron(II)," Geochimica et Cosmochimica Acta, vol. 63, no. 19-20, pp. 2939-2955, 1999.

[6] B. Gu, L. Liang, M. J. Dickey, X. Yin, and S. Dai, "Reductive precipitation of uranium(VI) by zero-valent iron," Environmental Science and Technology, vol. 32, no. 21, pp. 3366-3373, 1998.

[7] D. R. Lovley, "Dissimilatory metal reduction," Annual Review of Microbiology, vol. 47, pp. 263-290, 1993.

[8] D. R. Lovley, E. E. Roden, E. J. P. Phillips, and J. C. Woodward, "Enzymatic iron and uranium reduction by sulfate-reducing bacteria," Marine Geology, vol. 113, no. 1-2, pp. 41-53, 1993.

[9] D. R. Lovley, E. J. P. Phillips, Y. A. Gorby, and E. R. Landa, "Microbial reduction of uranium," Nature, vol. 350, no. 6317, pp. 413-416, 1991.
[10] D. R. Lovley and E. J. P. Phillips, "Bioremediation of uranium contamination with enzymatic uranium reduction," Environmental Science and Technology, vol. 26, no. 11, pp. 2228-2234, 1992.

[11] A. Kochenov, K. Korolev, V. Dubinchuk, and Y. Medvedev, "Experimental data on the conditions of precipitation of uranium from aqueous solutions," Geochemistry International, vol. 14, pp. 82-87, 1987.

[12] P. Wersin, M. F. Hochella Jr., P. Persson, G. Redden, J. O. Leckie, and D. W. Harris, "Interaction between aqueous uranium (VI) and sulfide minerals: spectroscopic evidence for sorption and reduction," Geochimica et Cosmochimica Acta, vol. 58, no. 13, pp. 2829-2843, 1994.

[13] L. N. Moyes, R. H. Parkman, J. M. Charnock et al., "Uranium uptake from aqueous solution by interaction with goethite, lepidocrocite, muscovite, and Mackinawite: an x-ray absorption spectroscopy study," Environmental Science and Technology, vol. 34, no. 6, pp. 1062-1068, 2000.

[14] C. E. Barnes and J. K. Cochran, "Uranium geochemistry in estuarine sediments: controls on removal and release processes," Geochimica et Cosmochimica Acta, vol. 57, no. 3, pp. 555-569, 1993.

[15] P. Wersin, M. F. Hochella Jr., P. Persson, G. Redden, J. O. Leckie, and D. W. Harris, "Interaction between aqueous uranium (VI) and sulfide minerals: spectroscopic evidence for sorption and reduction," Geochimica et Cosmochimica Acta, vol. 58, no. 13, pp. 2829-2843, 1994.

[16] F. R. Livens, M. J. Jones, A. J. Hynes et al., "X-ray absorption spectroscopy studies of reactions of technetium, uranium and neptunium with mackinawite," Journal of Environmental Radioactivity, vol. 74, no. 1-3, pp. 211-219, 2004.

[17] S. C. Brooks, J. K. Fredrickson, S. L. Carroll et al., "Inhibition of bacterial U(VI) reduction by calcium," Environmental Science and Technology, vol. 37, no. 9, pp. 1850-1858, 2003.

[18] B. Wielinga, B. Bostick, C. M. Hansel, R. F. Rosenzweig, and S. Fendorf, "Inhibition of bacterially promoted uranium reduction: ferric (Hydr)oxides as competitive electron acceptors," Environmental Science and Technology, vol. 34, no. 11, pp. 21902195, 2000.

[19] M. Dickinson and T. B. Scott, "The application of zerovalent iron nanoparticles for the remediation of a uraniumcontaminated waste effluent," Journal of Hazardous Materials, vol. 178, no. 1-3, pp. 171-179, 2010.

[20] O. Riba, T. B. Scott, K. Vala Ragnarsdottir, and G. C. Allen, "Reaction mechanism of uranyl in the presence of zero-valent iron nanoparticles," Geochimica et Cosmochimica Acta, vol. 72, no. 16, pp. 4047-4057, 2008.

[21] T. B. Scott, G. C. Allen, P. J. Heard, A. C. Lewis, and D. F. Lee, "The extraction of uranium from groundwaters on iron surfaces," Proceedings of the Royal Society A: Mathematical, Physical and Engineering Sciences, vol. 461, no. 2057, pp. 12471259, 2005.

[22] R. A. Crane, M. Dickinson, I. C. Popescu, and T. B. Scott, "Magnetite and zero-valent iron nanoparticles for the remediation of uranium contaminated environmental water," Water Research, vol. 45, no. 9, pp. 2931-2942, 2011.

[23] T. B. Scott, I. C. Popescu, R. A. Crane, and C. Noubactep, "Nanoscale metallic iron for the treatment of solutions containing multiple inorganic contaminants," Journal of Hazardous Materials, vol. 186, no. 1, pp. 280-287, 2011.

[24] S. Yan, B. Hua, Z. Bao, J. Yang, C. Liu, and B. Deng, "Uranium(VI) removal by nanoscale zerovalent iron in anoxic batch 
systems," Environmental Science and Technology, vol. 44, no. 20, pp. 7783-7789, 2010.

[25] S. Klimkova, M. Cernik, L. Lacinova, J. Filip, D. Jancik, and R. Zboril, "Zero-valent iron nanoparticles in treatment of acid mine water from in situ uranium leaching," Chemosphere, vol. 82, no. 8, pp. 1178-1184, 2011.

[26] R. A. Crane and T. B. Scott, "Nanoscale zero-valent iron: future prospects for an emerging water treatment technology," Journal of Hazardous Materials, vol. 211-212, pp. 112-125, 2012.

[27] R. A. Crane and T. B. Scott, "The effect of vacuum annealing of magnetite and zero-valent Iron nanoparticles on the removal of aqueous Uranium," Journal of Nanotechnology, vol. 2013, Article ID 173625, 11 pages, 2013.

[28] C. Noubactep, S. Caré, and R. Crane, "Nanoscale metallic iron for environmental remediation: prospects and limitations," Water, Air, and Soil Pollution, vol. 223, no. 3, pp. 1363-1382, 2012.

[29] C. Wang and W. Zhang, "Synthesizing nanoscale iron particles for rapid and complete dechlorination of TCE and PCBs," Environmental Science \& Technology, vol. 31, pp. 2154-2156, 1997.

[30] K. Ragnarsdottir and L. Charlet, "Uranium behaviour in natural environments. Environmental mineralogy-microbial interactions, anthropogenic influences, contaminated land and waste management," Mineralogical Society Series, vol. 9, pp. 245-289, 2000.

[31] H. Kurokawa and M. Senna, "Morphology control of goethite acicular particles during aging by nitrogen bubbling and subsequent reactive aeration," Journal of Materials Science, vol. 43, no. 14, pp. 4737-4741, 2008.

[32] L. Maya, "Hydrolysis and carbonate complexation of dioxouranium(VI) in the neutral-pH range at $25^{\circ} \mathrm{C}$," Inorganic Chemistry, vol. 21, no. 7, pp. 2895-2898, 1982.

[33] D. Harris, Quantitative Chemical Analysis, W. H. Freeman, New York, NY, USA, 6th edition, 2003.

[34] S. Das, M. J. Hendry, and J. Essilfie-Dughan, “Transformation of two-line ferrihydrite to goethite and hematite as a function of $\mathrm{pH}$ and temperature," Environmental Science and Technology, vol. 45, no. 1, pp. 268-275, 2011.

[35] L. E. Davidson, S. Shaw, and L. G. Benning, "The kinetics and mechanisms of schwertmannite transformation to goethite and hematite under alkaline conditions," American Mineralogist, vol. 93, no. 8-9, pp. 1326-1337, 2008.

[36] R. Cornell and U. Schwertmann, The Iron Oxides: Structure, Properties, Reactions, Occurrences and Uses, Wiley-VCH, 2003.

[37] T. Missana, M. García-Gutiérrez, and V. Fernńdez, "Uranium (VI) sorption on colloidal magnetite under anoxic environment: experimental study and surface complexation modelling," Geochimica et Cosmochimica Acta, vol. 67, no. 14, pp. 2543-2550, 2003.

[38] S. Mann, N. H. C. Sparks, S. B. Couling, M. C. Larcombe, and R. B. Frankel, "Crystallochemical characterization of magnetic spinels prepared from aqueous solution," Journal of the Chemical Society, Faraday Transactions 1: Physical Chemistry in Condensed Phases, vol. 85, no. 9, pp. 3033-3044, 1989.

[39] E. Murad, "Mossbauer and X-ray data on $\beta$-FeOOH (akaganéite)," Clay Minerals, vol. 14, pp. 273-283, 1979. 

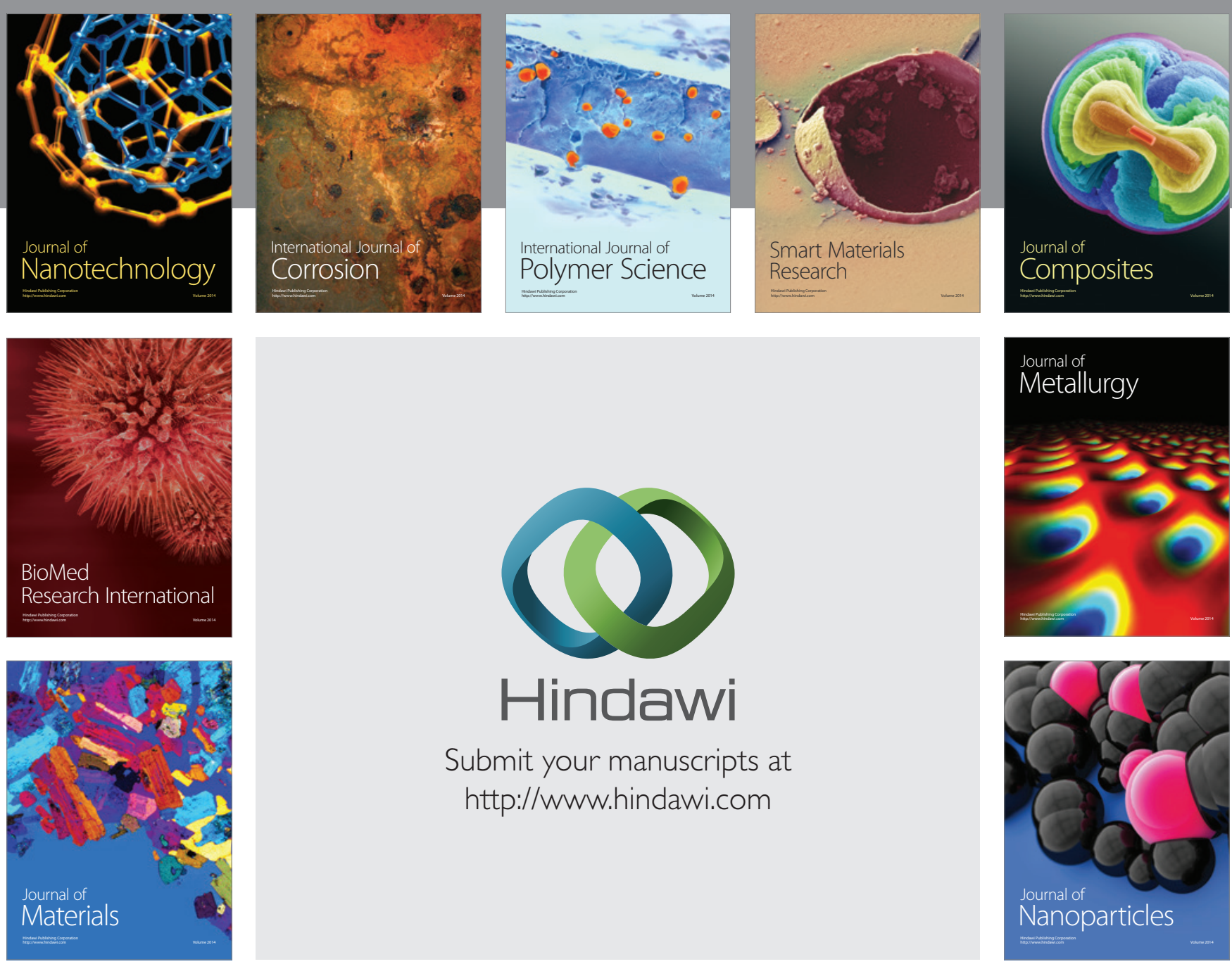

Submit your manuscripts at http://www.hindawi.com
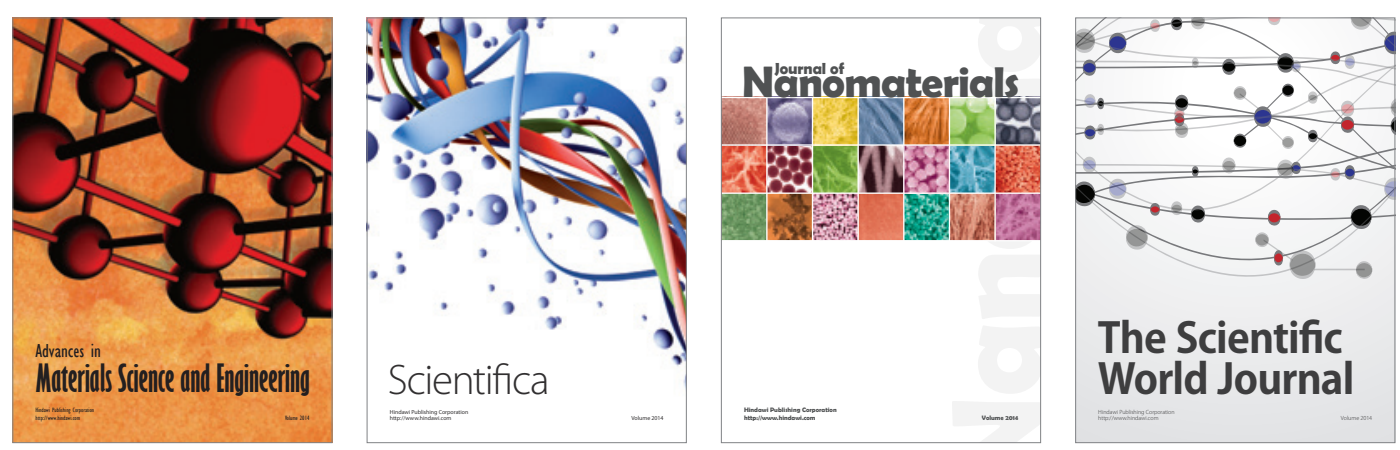

\section{The Scientific World Journal}
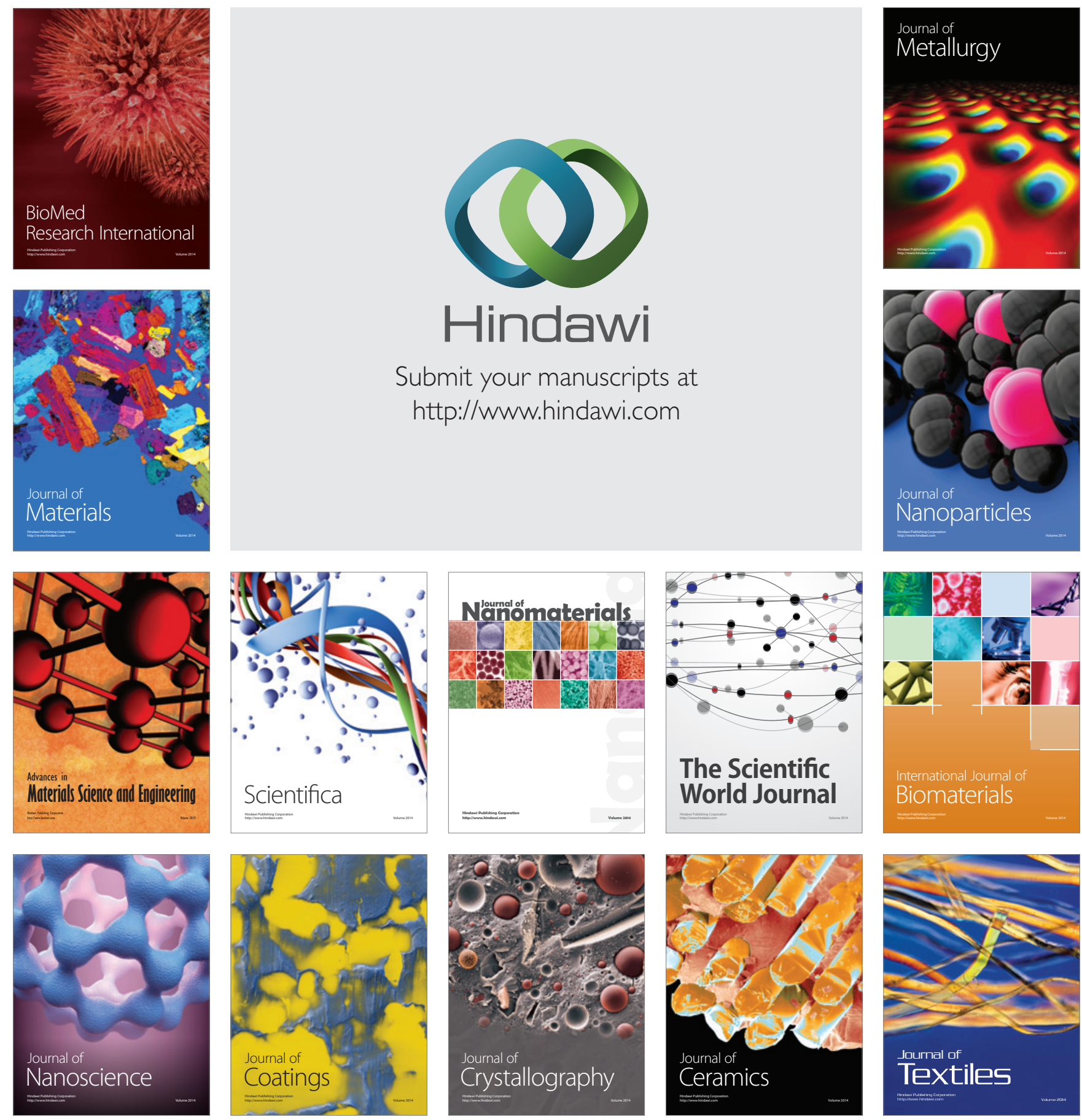